\title{
FLUKTUASI BULANAN HASIL TANGKAPAN CANTRANG YANG BERBASIS DI PELABUHAN PERIKANAN PANTAI TEGAL SARI, KOTA TEGAL
}

\author{
Tri Ernawati dan Bambang Sumiono \\ Peneliti pada Balai Riset Perikanan Laut, Muara Baru-Jakarta
}

Teregistrasi I tanggal: 26 Februari 2008; Diterima setelah perbaikan tanggal: 17 Nopember 2008;

Disetujui terbit tanggal: 12 Januari 2009

\begin{abstract}
ABSTRAK
Penelitian mengenai perikanan cantrang yang berkaitan dengan sumber daya ikan demersal sebagai hasil tangkapan utama dilaksanakan selama tahun 2006 - 2007. Penelitian ini bertujuan untuk mengetahui fluktuasi bulanan hasil tangkapan cantrang yang berbasis di Pelabuhan Perikanan Pantai Tegal Sari. Metode yang digunakan adalah survei yang meliputi pengambilan contoh dari hasil tangkapan, pencatatan buku bakul dan statistik perikanan pelabuhan. Hasil penelitian menunjukkan bahwa jumlah trip armada cantrang periode 2006 - 2007 didominansi oleh kapal berukuran 21 - 30 GT. Produksi bulanan Pelabuhan Perikanan Pantai Tegal Sari dari tahun 2004 - 2007 berfluktuasi. Secara umum, produksi bulanan pada bulan Nopember 2005 - Desember 2006 jauh lebih tinggi dibanding pada bulan-bulan di tahun 2004 dan 2007. Hal ini karena dipengaruhi oleh fluktuasi jumlah trip dan perkembangan unit penangkapan. Komposisi hasil tangkapan cantrang tahun 2006 berdasarkan pada hasil pengambilan contoh, didominansi oleh ikan coklatan (Scolopsis taeniopterus) (22\%), kuniran (Upeneus spp.) (17,4\%), dan swangi atau demang (Priachantus sp.) (9,7\%). Ratarata laju tangkap pada tahun 2006 dan 2007 berturut-turut 333,6 dan $424 \mathrm{~kg} / \mathrm{hari}$. Laju tangkap tahun 2006 cenderung, dipengaruhi oleh fluktuasi musiman, sedangkan laju tangkap tahun 2007 cenderung naik, tidak terpengaruh oleh fluktuasi musiman. Daerah penangkapan armada cantrang yang berbasis di Pelabuhan Perikanan Pantai Tegal Sari adalah di sekitar pantai timur Lampung, Tanjung Selatan (Kalimantan Selatan), dan Tanjung Puting (Kalimantan Tengah).
\end{abstract}

KATAKUNCI: cantrang, fluktuasi, hasil tangkapan, cantrang, Tegal Sari

ABSTRACT: Monthly fluctuation of the danish seine catch in Tegal Sari landing based on Tegal City. By: Tri Ernawati and Bambang Sumiono

The research on danish seine fishery related to demersal fish resources as the main catch was carried out from 2006 - 2007. The research aimed to know monthly fluctuation of the danish seine catch in Tegal Sari landing base. The survey was conducted by sampling the catch, recording data from retailer's book and landing base statistic. The results showed that number of trip from 2006 2007 was dominated by 21 to 30 GT vessel. Monthly production in Tegal Sari landing base on 2004 to 2007 was fluctuated. Generally, monthly production on November 2005 - Desember 2006 was higher than other months on 2004 and 2007. It was caused by fluctuation of trips number and unit fishing developement. The catch composition in 2006 based on sampling result, was dominated by lattice monocle bream (Scolopsis taenipterus) (22\%), goatfish (Upeneus spp.) (17.4\%), and purple spotted bigeye (Priachantus spp.) (9.7\%). Average of catch rate in 2006 and 2007 was 335.6 and $424 \mathrm{~kg}$ per day, respectively. The catch rate in 2006 danish seine, Tegal Sari tended to be influenced by season fluctuation. While catch rate in 2007 increased and was not influenced by season. Fishing grounds of danish seine fleet in Tegal Sari landing base were in eastern coast of Lampung waters, Tanjung Selatan (South Kalimantan) and Tanjung Puting (Central Kalimantan), respectively.

KEYWORDS: $\quad$ danish seine, fluctuation, catch rate, danish seine, Tegal Sari

\section{PENDAHULUAN}

Sejak pelarangan penggunaan traw/tahun $1980 \mathrm{di}$ perairan Laut Jawa, nelayan di wilayah Jawa banyak beralih menggunakan cantrang. Alat tangkap ini digolongkan sebagai jaring traw/semu (shadow traw) yang banyak digunakan di pantai utara Jawa, pantai selatan Jawa dan Lampung (Subani \& Barus, 1989).
Selama dua dasa warsa terakhir ini telah berkembang alat tangkap cantrang yang digunakan secara luas untuk menangkap ikan demersal (Badrudin et al., 1998). Cantrang merupakan alat tangkap yang cukup efektif untuk memanfaatkan sumber daya ikan demersal (Suhendrata \& Pawarti, 1991). Junus et al. (1994) menambahkan bahwa alat tangkap cantrang sangat efektif untuk menangkap ikan demersal 
berukuran kecil. Pengembangan usaha perikanan tangkap telah memungkinkan terjadinya perubahan teknologi perikanan tangkap di wilayah Laut Jawa, termasuk cantrang yang merupakan modifikasi dari alat tangkap trawl. Alat tangkap cantrang berkembang cukup pesat dan meluas, salah satunya yang berbasis di Pelabuhan Perikanan Pantai Tegal Sari, Kota Tegal.

Perikanan cantrang di Kota Tegal sejak pelarangan traw/ pada tahun 1980, mulai berkembang kembali tahun 1989 (Hadisubroto, 1992). Dalam perkembangannya, mesin kapal cantrang telah mengalami perubahan dari penggunaan mesin motor tempel menjadi mesin tetap (inboard). Ukuran kapal cantrang relatif besar dengan bobot kapal pada umumnya 20 - 30 GT, dengan lama tripnya mencapai 25 hari. Pada umumnya pengoperasian jaring cantrang dilakukan pada kedalaman 15 - 40 m. Pada proses pengoperasiannya, kapal bergerak perlahan-lahan untuk mengimbangi gaya akibat dari penurunan dan penarikan jaring tersebut.

Pelabuhan Perikanan Pantai Tegal Sari merupakan salah satu basis perikanan cantrang di pesisir utara Jawa yang diresmikan pada tanggal 4 Juli 2004 oleh Presiden Megawati. Sebelum menjadi pelabuhan perikanan, Pelabuhan Perikanan Pantai Tegal Sari hanya merupakan tempat pendaratan ikan yang pada umumnya menampung kapal-kapal kecil di bawah ukuran 5 GT. Setelah Pelabuhan Perikanan Pantai Tegal Sari mulai aktif digunakan, produksi ikan, khususnya ikan demersal, relatif meningkat dibandingkan dengan sebelum menjadi pelabuhan perikanan, meskipun perairan Laut Jawa diketahui sebagai daerah yang sudah padat tangkap (fully exploited). Hasil tangkapan cantrang yang banyak tertangkap adalah ikan-ikan demersal yang berukuran relatif kecil, antara lain kuniran (Upeneus sulphureus), peperek (Leiognathus bindus), coklatan (Scolopsis taeniopterus), swangi (Priacanthus sp.), beloso (Saurida undosquamis), kapasan (Pentaprion longimanus), dan lain-lainnya.

Tulisan ini bertujuan untuk mengetahui fluktuasi bulanan hasil tangkapan cantrang yang berbasis di Pelabuhan Perikanan Pantai Tegal Sari. Diharapkan informasi ini dapat dijadikan pertimbangan dalam pengelolaan dan pengembangan perikanan cantrang.

\section{BAHAN DAN METODE}

\section{Pengumpulan Data}

Kegiatan penelitian dilakukan pada tahun 2006 dan 2007 di Pelabuhan Perikanan Pantai Tegal Sari yang merupakan pusat pendaratan kapal cantrang di Kota Tegal.

Data hasil tangkapan menurut jenis ikan per kapal diperoleh dari pemilik kapal dalam bentuk buku bakul. Data mengenai produksi, GT, dan jumlah kapal per bulan diperoleh dari statistik perikanan Pelabuhan Perikanan Pantai Tegal Sari. Komposisi jenis ikan diperoleh dari rata-rata hasil tangkapan selama survei periode bulan Pebruari - Oktober 2006. Informasi mengenai lama operasi dan daerah penangkapan diperoleh dari hasil wawancara dengan nahkoda kapal dan anak buah kapal.

\section{Analisis Data}

Analisis data dilakukan untuk memperoleh dugaan laju tangkap tiap bulan. Untuk menghitung laju tangkap tiap bulan (dalam kg per hari) diperoleh:

$$
C=B / A
$$

di mana:

$$
\begin{aligned}
A= & \text { jumlah hari efektif dihitung dari nilai rata-rata } \\
& \text { hari efektif kapal cantrang contoh tiap bulan } \\
& \text { kemudian dikalikan dengan jumlah trip pada } \\
& \text { setiap bulan (hari) } \\
\mathrm{B}= & \text { jumlah produksi kapal cantrang pada setiap } \\
& \text { bulan }(\mathrm{kg}) \\
\mathrm{C}= & \text { laju tangkap tiap bulan (kg per hari) }
\end{aligned}
$$

Data mengenai daerah penangkapan diklasifikasi dan dianalisis secara deskriptif kemudian ditampilkan dalam gambar peta.

\section{HASIL DAN BAHASAN}

\section{Komposisi Ukuran Kapal (GT) dan Jumlah Trip}

Pada periode tahun 2006, ukuran kapal cantrang yang berbasis di Pelabuhan Perikanan Pantai Tegal Sari berkisar 5 - 30 GT. Tabel 1 menampilkan jumlah trip keseluruhan dalam satu tahun (3.485) yang didominansi oleh ukuran 21 - 30 GT sekitar $60 \%$ lebih atau 2.106. Jumlah trip pada periode tahun 2007 adalah 1.442 (Tabel 2), sekitar 80\% atau 1.132, didominansi oleh ukuran 21 - 30 GT. Bila dibandingkan dengan jumlah trip periode tahun 2006, jumlah trip tahun 2007 pada periode yang sama mengalami penurunan yang cukup signifikan. Pada periode tahun 2006, rata-rata trip tiap bulan adalah 290 , sedangkan rata-rata trip tahun 2007 adalah 120. Hal ini dipengaruhi oleh kondisi cuaca yang buruk selama periode tahun 2007 dan sering adanya larangan berlayar dari Badan Meteorologi dan Geofisika. 
Tabel 1 Table1.

Jumlah trip kapal cantrang bulanan di Pelabuhan Perikanan Pantai Tegal Sari, tahun 2006 Monthly number of trip of danish seine boats in landing place Tegal Sari, 2006

\begin{tabular}{|c|c|c|c|c|c|}
\hline \multirow{2}{*}{ Bulan/Month } & \multicolumn{4}{|c|}{ GT } & \multirow{2}{*}{ Total/Tota } \\
\hline & $5-10$ & $11-20$ & $21-30$ & $30<$ & \\
\hline Januari & 66 & 63 & 203 & 2 & 334 \\
\hline Pebruari & 51 & 44 & 163 & 3 & 261 \\
\hline Maret & 54 & 66 & 208 & 1 & 329 \\
\hline April & 72 & 59 & 179 & 1 & 311 \\
\hline Mei & 71 & 49 & 174 & 1 & 295 \\
\hline Juni & 87 & 38 & 173 & 1 & 299 \\
\hline Juli & 102 & 37 & 174 & 0 & 313 \\
\hline Agustus & 111 & 42 & 192 & 0 & 345 \\
\hline September & 77 & 41 & 197 & 1 & 316 \\
\hline Oktober & 51 & 35 & 139 & 1 & 226 \\
\hline Nopember & 57 & 25 & 152 & 2 & 236 \\
\hline Desember & 32 & 34 & 152 & 2 & 220 \\
\hline Total/Total & 831 & 533 & 2106 & 15 & 3.485 \\
\hline Rata-rata/Average & 69,3 & 44,4 & 175,5 & 1,3 & 290 \\
\hline
\end{tabular}

Tabel 2. Jumlah trip kapal cantrang bulanan di Pelabuhan Perikanan Pantai Tegal Sari, tahun 2007 Table 2. Monthly number of trip of danish seine boats in landing place Tegal Sari, 2007

\begin{tabular}{|c|c|c|c|c|c|}
\hline \multirow{2}{*}{ Bulan/Month } & \multicolumn{4}{|c|}{ GT } & \multirow{2}{*}{ Total/ Total } \\
\hline & $5-10$ & $11-20$ & $21-30$ & $30<$ & \\
\hline Januari & 19 & 19 & 93 & 1 & 132 \\
\hline Pebruari & 10 & 16 & 87 & 1 & 114 \\
\hline Maret & 7 & 5 & 80 & & 92 \\
\hline April & 3 & 7 & 78 & 1 & 89 \\
\hline Mei & 6 & 6 & 75 & 1 & 88 \\
\hline Juni & 7 & 4 & 52 & & 63 \\
\hline Juli & 31 & 15 & 131 & 2 & 179 \\
\hline Agustus & 20 & 17 & 129 & & 166 \\
\hline September & 27 & 15 & 129 & 1 & 172 \\
\hline Oktober & 13 & 10 & 75 & & 98 \\
\hline Nopember & 10 & 12 & 117 & 2 & 141 \\
\hline Desember & 9 & 13 & 86 & & 108 \\
\hline Total/Total & 162 & 139 & 1.132 & 9 & 1.442 \\
\hline Rata-rata/Average & 13,5 & 11,6 & 94,3 & 0,8 & 120 \\
\hline
\end{tabular}

\section{Produksi}

Produksi bulanan di Pelabuhan Perikanan Pantai Tegal Sari dari tahun 2004 - 2007 berfluktuasi (Gambar 1). Secara umum, produksi bulanan pada bulan Nopember 2005 - Desember 2006 lebih tinggi dibandingkan pada bulan-bulan di tahun 2004 dan 2007. Rata-rata produksi bulanan masing-masing tahun adalah 2004 (171,2 ton), 2005 (476 ton), 2006 (1.458,6 ton), dan 2007 (781,9 ton). Kondisi ini disebabkan pada periode tahun 2004 - 2005 Pelabuhan Perikanan Pantai Tegal Sari belum berfungsi optimal, banyak pembenahan-pembenahan, dan peningkatanpeningkatan fasilitas yang memadai. Oleh karena itu, kapal-kapal cantrang yang memungkinkan untuk bongkar muat jenis kapal-kapal kecil ukuran <5 GT. Sedangkan kapal-kapal cantrang berukuran besar yang menampung hasil tangkapan jauh lebih banyak, baru mulai dapat difasilitasi maksimal untuk bongkar muat di Pelabuhan Perikanan Pantai Tegal Sari pada akhir tahun 2005.

Berdasarkan Gambar 1, produksi bulanan pada 2004 terjadi lonjakan produksi yang cukup tinggi di bulan Agustus, dari produksi di bawah 150 ton naik menjadi 785 ton atau sekitar $500 \%$, dan di bulan-bulan berikutnya mengalami penurunan sampai di bawah 150 ton. Hal ini diduga pada bulan Agustus terdapat kelimpahan ikan demersal di lahan-lahan yang merupakan bagian dari daerah penangkapan nelayan, 

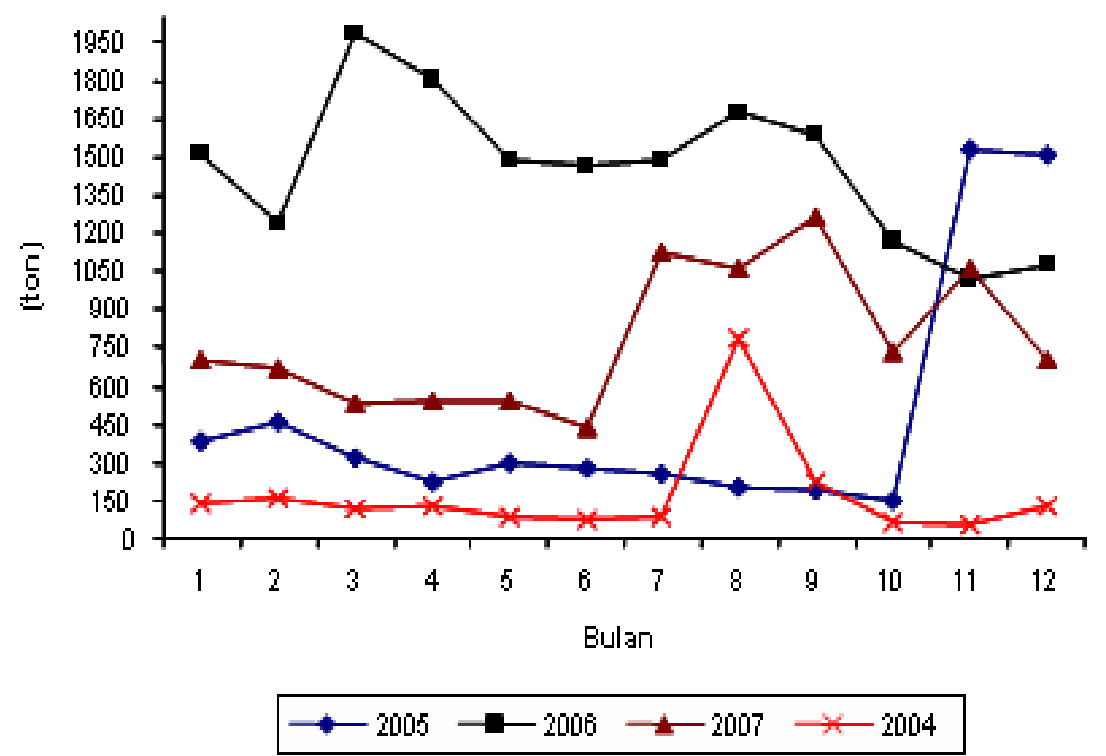

Gambar 1. Produksi total bulanan di Pelabuhan Perikanan Pantai Tegal Sari tahun 2004 - 2007. Figure 1. Total monthly production in Tegal Sari landing base during period of 2004 to 2007.

misalnya di perairan timur Sumatera. Produksi bulanan pada tahun 2005 juga terjadi lonjakan produksi yang tinggi di bulan Nopember dan Desember dibandingkan dengan bulan-bulan sebelumnya (sekitar $550 \%$ ). Hal ini disebabkan adanya peningkatan upaya penangkapan, mulai beroperasinya kapal-kapal cantrang besar berukuran di atas 10 GT dengan hari operasi rata-rata 15 hari. Kapal-kapal tersebut memiliki kemampuan jelajah dalam mencari ikan lebih luas dan kemampuan menampung hasil tangkapan juga jauh lebih banyak dibanding kapal-kapal cantrang berukuran $5 \mathrm{GT}$ atau di bawahnya.

Produksi bulanan pada tahun 2006 sangat berfluktuatif. Produksi bulanan yang tinggi mencapai lebih dari 1.600 ton yang terjadi di bulan Maret, April, Agustus, dan September, namun yang tertinggi pada bulan Maret yang mencapai 1.984 ton. Produksi bulanan yang rendah di bawah 1.250 ton terjadi di bulan Pebruari, Oktober, Nopember, dan Desember, namun yang terendah terjadi di bulan Nopember (1.020 ton). Kondisi ini dipengaruhi oleh jumlah upaya penangkapan yang sedikit. Jumlah upaya penangkapan pada bulan Pebruari dan Oktober sampai Desember 2006 cukup sedikit dibanding pada bulan-bulan lainnya (Tabel 1). Untuk produksi bulanan tahun 2007, sampai pertengahan tahun pertama terus mengalami penurunan yang cukup signifikan sampai mencapai 436 ton di bulan Juni. Rata-rata produksi bulanan sampai bulan Juni adalah 571 ton. Namun, pada periode selanjutnya sampai bulan Desember 2007 kembali mengalami peningkatan, dengan rata- rata produksi bulanan sekitar 993 ton. Hal ini disebabkan oleh kondisi cuaca yang sangat tidak menguntungkan bahkan sering dikeluarkan larangan untuk berlayar oleh Badan Meteorologi dan Geofisika. Hal ini berpengaruh terhadap penurunan jumlah trip penangkapan sampai bulan Juni 2007 , seperti yang tertera pada Tabel 2. Pada periode berikutnya, jumlah trip mulai meningkat sehingga mempengaruhi kenaikan produksi.

Produksi ikan tahun 2006 - 2007 (Gambar 2, 3), jenis ikannya yang mendominansi hasil tangkapan cantrang tidak mengalami perubahan. Berturut-turut jenis yang selalu mendominansi antara lain ikan kuniran (Upeneus spp), peperek atau petek (Leiognathus spp.), coklatan (Scolopsis taeniopterus), kapasan (Pentaprion longimanus), swangi (Priachantus spp.), manyung (Arius spp.), dan pari (Himantura spp. dan Dasyatis sp.). Pada tahun 2006, puncak-puncak produksi terjadi pada bulan Maret dan September, hal ini disebabkan karena jumlah upaya yang cukup banyak dan kondisi cuaca yang mendukung kegiatan penangkapan. Sedangkan pada periode bulan Januari - Juni 2007, produksinya terus mengalami penurunan. Karena pada sepanjang periode tersebut, kondisi cuaca sangat tidak mendukung untuk kegiatan penangkapan, sehingga jumlah upaya penangkapan pun menurun. Kemudian pada periode bulan Juli - Desember 2007, produksi mengalami kenaikan kembali seiring dangan meningkatnya jumlah upaya penangkapan. 


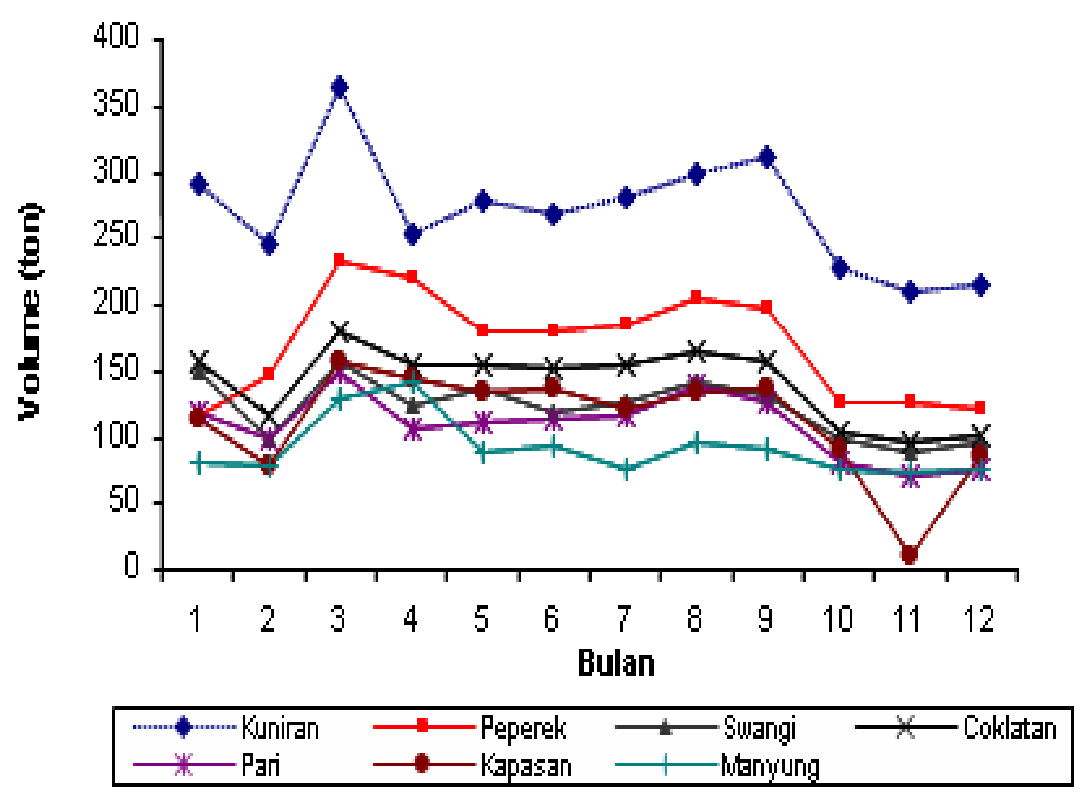

Gambar 2. Produksi ikan dominan didaratkan di Pelabuhan Perikanan Pantai Tegal Sari, tahun 2006. Figure 2.
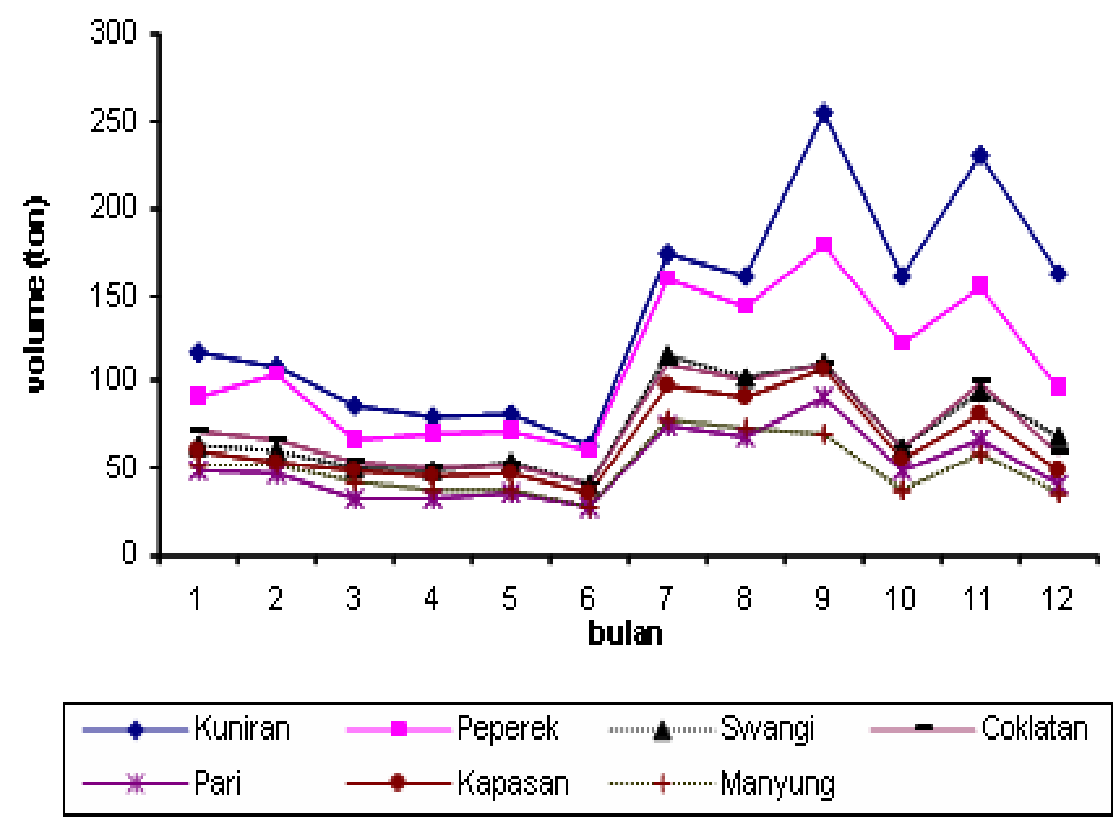

Gambar 3. Produksi ikan dominan didaratkan di Pelabuhan Perikanan Pantai Tegal Sari, tahun 2007. Figure 3. Production of dominant species landed in Tegal Sari landing base, 2007.

\section{Hasil Tangkapan}

\section{a. Komposisi Hasil Tangkapan}

Komposisi hasil tangkapan cantrang tahun 2006 (Tabel 3), bila dibandingkan dengan hasil pengamatan tahun 1992, menunjukkan terjadinya perubahan, antara lain kenaikan pada jenis bambangan (Lutjanus spp.), beronang (Siganus spp.), kapasan, manyung, dan pari. Penurunan pada jenis beloso (Saurida spp.), gulamah (Johnius sp.), swangi, kurisi (Nemipterus spp.), petek (Leiognathus spp), dan selar dan gontor 
Tabel 3. Rata-rata hasil tangkapan cantrang di Pelabuhan Perikanan Pantai Tegal Sari (data dari 18 kapal antara bulan Pebruari - Oktober 2006)

Table 3. Average of catch composition by danish seine boats in Tegal Sari landing base (data collected from 18 boats February - October 2006)

\begin{tabular}{lccc}
\hline \multicolumn{1}{c}{ Jenis/Species } & kg & $\%$ & \% (Tegal Sari, 1992*) \\
\hline Bambangan (Lutjanus spp.) & 349,4 & 5,18 & 0,04 \\
Beloso/Balakan (Saurida spp.) & 263,0 & 3,90 & 6,1 \\
Beronang/Smadar (Siganus spp.) & 140,2 & 2,08 & 0,1 \\
Blamah (Scianidae) & 322,6 & 4,78 & 5,19 \\
Bodolan (Gazza sp.) & 18,5 & 0,27 & - \\
Buntek (Tetraodontidae) & 187,9 & 2,78 & - \\
Coklatan (Scolopsis taeniopterus) & $1,871,4$ & 27,73 & - \\
Demang (Priachantus sp.) & 773,6 & 11,46 & 25,1 \\
Etong (Abalistes stellaris) & 72,8 & 1,08 & 0,3 \\
Getek (Psettodes erumei) & 5,7 & 0,08 & 0,1 \\
Kapas/Rengganis (Pentaprion longimanus) & 619,9 & 9,19 & 4,5 \\
Keting/Utik (Arius sp.) & 194,7 & 2,89 & \\
Klotok (Pomadasys argyreus) & 121,1 & 1,79 & 2,6 \\
Kerong-kerong (Therapon spp.) & 12,8 & 0,19 & 1,2 \\
Kuniran (Upeneus spp.) & $1.324,1$ & 19,62 & 17 \\
Kurisi (Nemipterus spp.) & 72,5 & 1,07 & 7,6 \\
Laosan (Polynemidae) & 13,1 & 0,19 & - \\
Manyung (Arius sp.) & 38,0 & 0,56 & 0,2 \\
Pari (Dasyatis kuhlii) & 113,1 & 1,68 & 0,8 \\
Patik (Drepane sp.) & 2,8 & 0,04 & - \\
Petek (Leioghnatus sp.) & 124,3 & 1,84 & 25,8 \\
Selar/Gontor (Selaroides leptolepis) & 76,3 & 1,13 & 1 \\
lain-lain & 30,7 & 0,46 & 10,89 \\
\hline Total/Total & $\mathbf{6 . 7 4 8 , 4}$ & & \\
\hline
\end{tabular}

Sumber/Sources: ") Hadisubroto (1992)

(Selaroides leptolepis). Sedangkan jenis-jenis yang lainnya relatif tetap dan ada beberapa jenis yang tidak tercatat pada tahun 1992 antara lain patik (Drepane sp.), laosan (Polynemidae), bodolan (Gazza sp.), buntek (Tetraodontidae), dan coklatan (Tabel 3). Komposisi hasil tangkapan pada tahun 1992 didominansi oleh petek (Leiognathus bindus), swangi atau demang (Priachantus sp.), kuniran, kurisi (Nemipterus spp.), beloso atau balakan (Saurida spp.), dan gulamah atau blamah (Johnius sp.). Sedangkan pada tahun 2006, didominansi oleh coklatan, kuniran, swangi atau demang, kapas atau rengganis (Pentaprion longimanus), pari dan manyung (Arius sp.). Terjadinya perubahan komposisi hasil tangkapan disebabkan adanya perubahan daerah penangkapan. Sadhotomo (1990) mengatakan bahwa ikan-ikan Pentaprion longimanus, Pomadasydae, Synodontidae, dan Nemipteridae merupakan taksonomik yang mencirikan komunitas karang atau pasir, sedangkan ikan-ikan seperti Leiognathidae dan Scianidae mencirikan komunitas demersal atau lumpur. Suhendrata \& Badrudin (1990) juga mengatakan bahwa perubahan komposisi hasil tangkapan disebabkan oleh pengaruh musim dan fluktuasi alat tangkap yang digunakan.

\section{b. Laju Tangkap Total}

Rata-rata laju tangkap ikan hasil tangkapan cantrang ukuran kapal 21 - 30 GT pada tahun 2006 dan 2007 berturut-turut adalah 333,6 dan $424 \mathrm{~kg}$ per hari. Gambar 4 memperlihatkan bahwa laju tangkap tahun 2006 cenderung dipengaruhi oleh fluktuasi musim. Pada musim peralihan I (Maret - Mei), laju tangkap lebih tinggi daripada musim-musim lainnya. Laju tangkap tahun 2007 tidak begitu dipengaruhi oleh fluktuasi musim dan laju tangkap cenderung terus naik sampai akhir tahun. Kondisi ini disebabkan oleh jumlah upaya penangkapan pada tahun 2007 mengalami penurunan yang cukup signifikan sampai mencapai sekitar $60 \%$ bila dibandingkan dengan tahun 2006. Penurunan ini karena kondisi cuaca yang tidak mendukung untuk melakukan operasi penangkapan. 

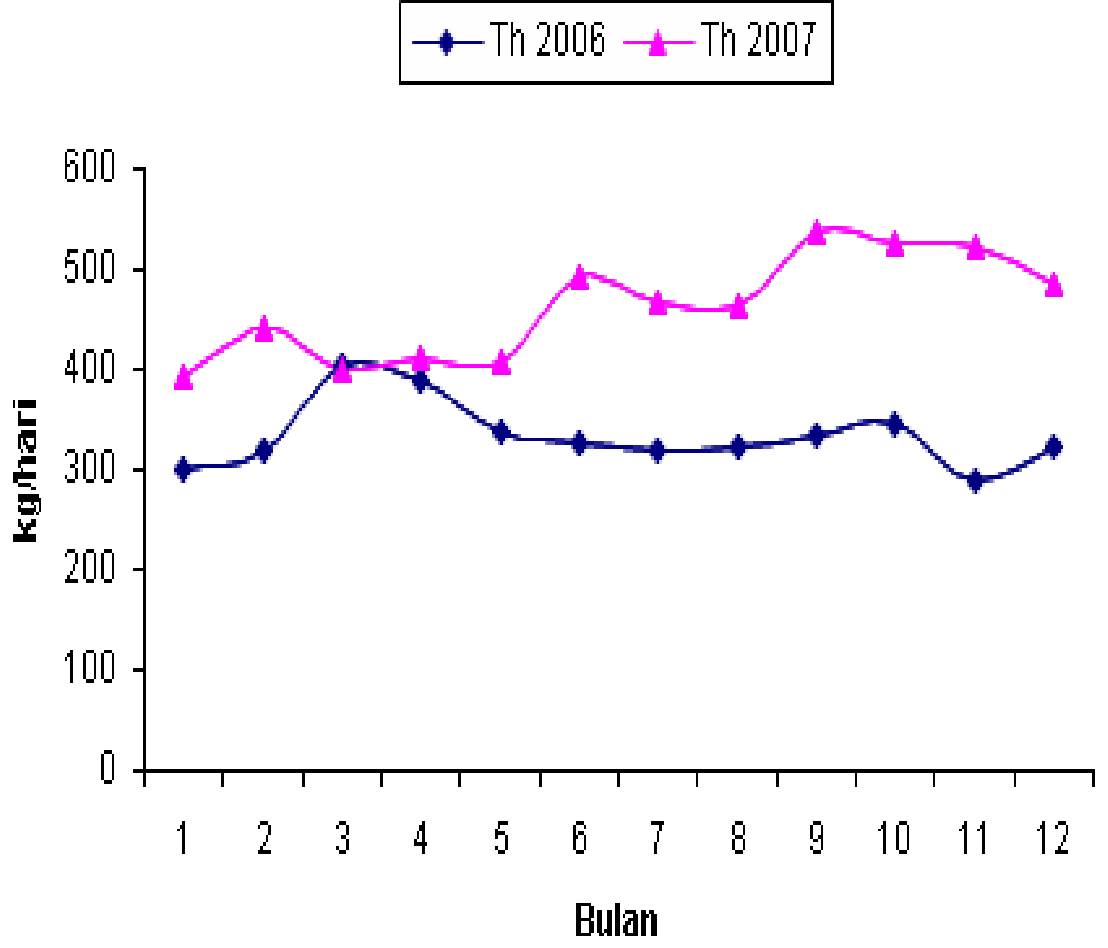

Gambar 4. Laju tangkap hasil tangkapan cantrang periode tahun 2006 dan 2007 dengan ukuran kapal 21 - 30 GT di Pelabuhan Perikanan Pantai Tegal Sari.

Figure 4. Catch rate of danish seine on 2006 and 2007 periods using boat's size of 21 - 30 GT in Tegal Sari landing base.

\section{Daerah Penangkapan}

Daerah penangkapan armada cantrang dengan rata-rata ukurun kapal di atas 15 GT yang berbasis di Pelabuhan Perikanan Pantai Tegal Sari adalah di sekitar pantai timur Lampung, Tanjung Selatan, dan Tanjung Puting (Gambar 5). Pada musim timur di mana angin tenggara berhembus kencang telah menyebabkan timbulnya kawasan-kawasan perairan yang teduh di perairan Tanjung Selatan dan Tanjung Puting. Sebaliknya, pada periode musim barat di mana kawasan yang relatif teduh terjadi di perairan pantai timur Lampung. Menurut Ernawati (2003), daerah penangkapan di perairan pantai timur Lampung antara lain adalah di sekitar Pantai Mundu, muara Sungai Sekampung, Maringgai, Seputih, dan Kambas sampai Tanjung Sekopong.

Bila dicermati, jarak tempuh nelayan dari Pelabuhan Perikanan Pantai Tegal Sari menuju daerah penangkapan relatif jauh, memakan waktu 2 3 hari. Kondisi ini menyebabkan biaya operasional cukup besar terutama biaya bahan bakar minyak. Namun demikian, nelayan selalu beroperasi di daerah penangkapan tersebut. Hal ini tentu berkaitan dengan kelimpahan sumber daya ikan demersal di sekitar perairan pantai utara Jawa yang sudah semakin menipis, sedangkan di daerah-daerah penangkapan tersebut cukup berlimpah. Kondisi tersebut disebabkan oleh tingginya intensitas penangkapan ikan demersal di wilayah utara Jawa yang dilakukan sepanjang hari sepanjang tahun, sehingga dikhawatirkan akan mengancam kelestarian dan keberlanjutan pemanfaatan sumber daya ikan di perairan tersebut. Apalagi hal ini terjadi pada sumber daya ikan demersal yang sangat rentan terhadap dampak penangkapan mengingat sifatnya yang memiliki ruaya yang sempit, aktivitas rendah, dan kawanan relatif kecil (Aoyama,1973). 


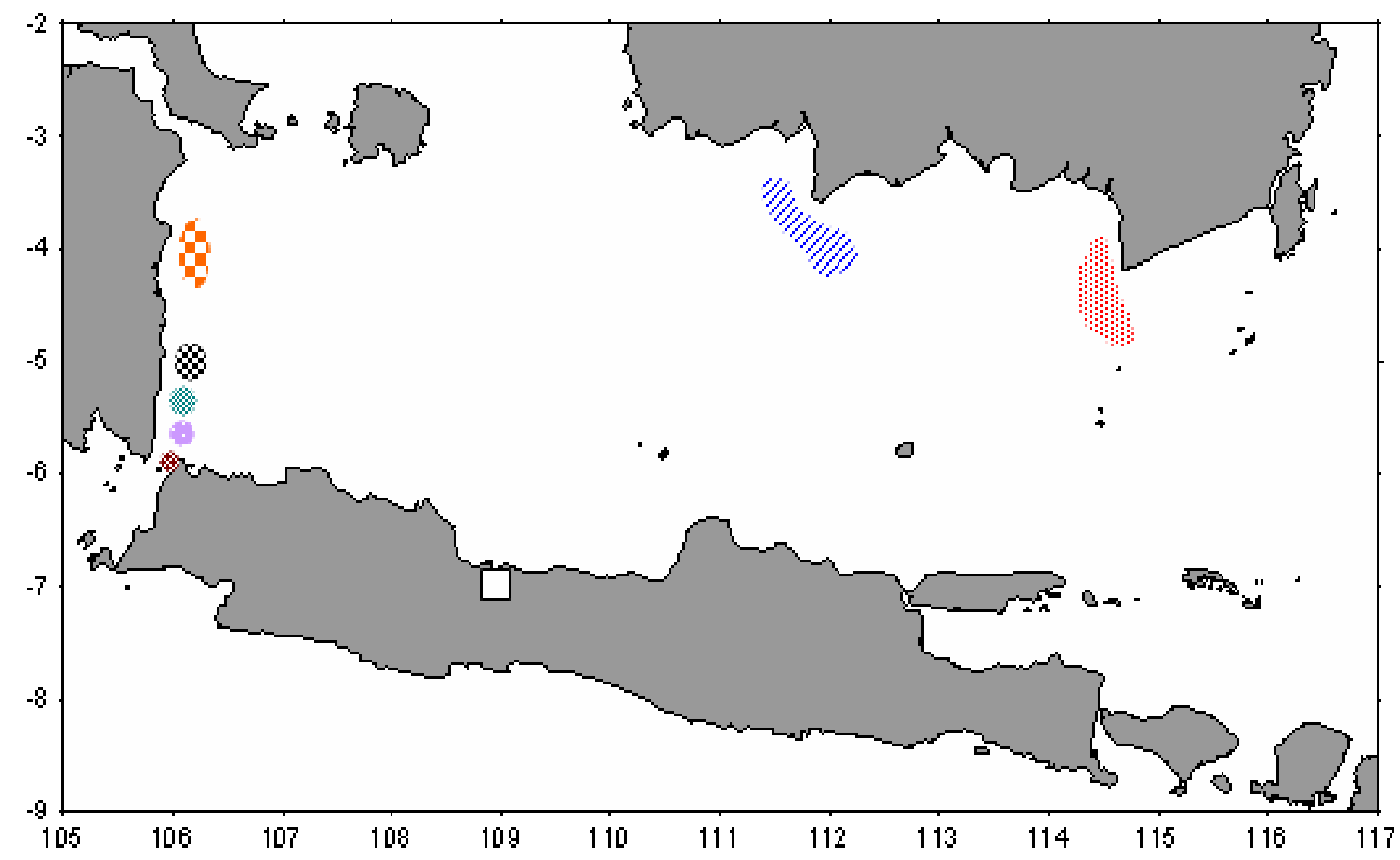

Keterangan/Remarks:

\begin{tabular}{|l}
$\mathscr{W} / / /$ Tanjung Putting \\
Tanjung Selatan \\
Pantai Mundu \\
Muara Sungai Sekampung
\end{tabular}

Maringgai

\% Muara Sungai Kambas-Tanjung Sekopong Muara Sungai Seputih

Gambar 5. Daerah penangkapan armada cantrang yang berbasis di Pelabuhan Perikanan Pantai Tegal Sari.

Figure 5. $\quad$ Fishing ground of danish seine fleet at Tegal Sari landing base.

\section{KESIMPULAN}

1. Produksi bulanan Pelabuhan Perikanan Pantai Tegal Sari dari tahun 2004 - 2007 berfluktuasi. Secara umum, produksi bulanan pada bulan Nopember 2005 - Desember 2006 jauh lebih tinggi dibanding pada bulan-bulan di tahun 2004 dan 2007.

2. Rata-rata laju tangkap ikan hasil tangkapan cantrang pada tahun 2006 dan 2007 berturut-turut adalah 333,6 dan $424 \mathrm{~kg}$ per hari. Laju tangkap tahun 2006 cenderung dipengaruhi oleh fluktuasi musiman, sedangkan laju tangkap tahun 2007 cenderung naik, tidak terpengaruh oleh fluktuasi musiman.

\section{PERSANTUNAN}

Kegiatan dari hasil riset pengkajian stok, life history, dan dinamika populasi sumber daya ikan demersal dan udang penaeid di Laut Cina Selatan,
Laut Jawa, dan Selat Makassar, T. A. 2006, di Balai Riset Perikanan Laut, Muara Baru-Jakarta.

\section{DAFTAR PUSTAKA}

Aoyama, T. 1973. The Demersal Fish Stock and Fisheries of the South China Sea. IPCF/SCC/Dev/ 73/3. 80. Rome.

Badrudin, M., G. H Tampubolon, B. Iskandar P. S., P. Raharjo, \& R. Basuki. 1998. Sumber Daya Ikan Demersal. Potensi dan Penyebaran Sumber Daya Ikan Laut di Perairan Indonesia. Komisi Nasional Pengkajian Stok Sumber Daya Ikan Laut. Jakarta.

Ernawati, T. 2003. Daerah operasi dan produktivitas armada perikanan tangkap yang berbasis di Kronjo Tangerang. Skripsi. Program Studi Pemanfaatan Sumber Daya Perikanan. Fakultas Perikanan dan IImu Kelautan. Institut Pertanian Bogor. Bogor. 
Hadisubroto, I. 1992. Perikanan cantrang di Kotamadya Tegal. Jurnal Penelitian Perikanan Laut. No.75.

Junus, S., R. Djamal, \& S. Karyaningsih. 1994. Perikanan cantrang dan beberapa aspeknya (Studi kasus Pemalang). Jurnal Penelitian Perikanan Laut. No.88.

Sadhotomo, B. 1990. Ordinasi komunitas ikan demersal di pantai utara Jawa I: Penentuan unit komunitas. Jurnal Penelitian Perikanan Laut. No.56.
Suhendrata, T. \& M. Badrudin. 1990. Sumber daya perikanan demersal di perairan pantai utara Rembang. Jurnal Penelitian Perikanan Laut. No.54.

Suhendrata, T. \& M. D. M. Pawarti. 1991. Perikanan cantrang dan prospek pengembangannya di perairan Kabupaten Dati II Batang. (in press).

Subani, W. \& H. R.Barus. 1989. Alat penangkapan ikan dan udang laut di Indonesia. Jurnal Penelitian Perikanan Laut. 